\title{
IZAZOVI KNJIŽNIČNE ARHITEKTURE ZA MLADE
}

\author{
THE CHALLENGES OF LIBRARY \\ ARCHITECTURE FOR YOUNG ADULTS
}

\author{
Marta Kasap ${ }^{1}$ \\ marta.kasap@gmail.com \\ Tatjana Aparac-Jelušić, prof. u miru \\ aparact@gmail.com
}

\author{
$\mathrm{UDK} / \mathrm{UDC}$ \\ 027.3-053.6:[022:727](497.5 Zadar) \\ Izvorni znanstveni rad / Original scientific paper \\ Prihvaćeno / Accepted: 2. 6. 2017.
}

\section{Sažetak}

Ovaj rad nastoji upotpuniti prazninu u hrvatskoj stručnoj literaturi na temu izgradnje knjižničnih prostora za mlade i unutarnjeg oblikovanja tih prostora.

$\mathrm{U}$ radu su predstavljeni metodologija i rezultati istraživanja provedenog u Gradskoj knjižnici Zadar, koja je odabrana iz dvaju razloga: zato što se najavljuje njezino proširenje i zato što je među knjižničnim djelatnicima i pojedincima iz lokalne samouprave prepoznata potreba da se mladima osigura poseban prostor.

1 Ovaj je članak nastao na osnovi diplomskog rada studentice Marte Kasap pod mentorskim vodstvom prof. dr. sc. Tatjane Aparac-Jelušić. Kako se radi o jednom od rijetkih istraživanja na temu uključivanja mladih u oblikovanje prostora za njihove potrebe te zanimanju studentice za pitanja knjižnične arhitekture, istraživanje je nastavljeno i nakon obrane diplomskog rada s još jednom fokus-skupinom i intervjuima sa stručnjacima. Smatrali smo da će rezultati istraživanja pridonijeti razumijevanju specifičnih okolnosti vezanih uz prostore i usluge za mlade. Također, iz mentorskog kuta gledanja učinilo se vrijednim podržati pristup koji će možda zainteresirati ne samo knjižničarsku zajednicu već i donositelje odluka u području društvenih djelatnosti u Gradu Zadru.

Vjesnik bibliotekara Hrvatske 60, 2-3(2017), 153-174

ISSN 0507-1925

(C) VBH 2017. 
Prvi je istraživački cilj bio utvrditi kako mladi reagiraju na predstavljene vizualne prikaze knjižnica, a drugi je cilj bio usmjeren prema iskazu njihovih vlastitih potreba za mogućim prostorom i aktivnostima u potencijalno raspoloživom prostoru za širenje sadašnje knjižnice te prikupljanju njihovih stavova o organizaciji i uređenju novog prostora. Treći je cilj istraživanja bio utvrditi stavove knjižničara i stručnjaka koji rade s mladima u odnosu na prostore za mlade, njihovo oblikovanje i opremanje.

U istraživanju se pošlo od pretpostavke da mladi žele svoj prostor i da imaju ideje o tome kako taj prostor urediti te da knjižničari očekuju da bi se u knjižnicu mogao privući veći broj mladih ako bi njima namijenjen prostor bio privlačan, funkcionalan i ugodan.

Istraživanje je provedeno primjenom kvalitativne metode istraživanja uz uporabu instrumenta fokus-skupine i intervjua, a odvijalo se tijekom 2015. godine.

Rezultati istraživanja ukazuju na to da su svi ispitanici svjesni potrebe za novim, prilagodljivim, privlačnijim i ugodnijim prostorom, u kojem bi bilo moguće ponuditi i niz novih usluga.

Ključne riječi: mladi, arhitektura knjižnica, knjižnica za mlade

\section{Summary}

This article is written with the intention to fill up the gap in the Croatian professional literature concerning the topic of building and designing the library space for young adults.

The first part of the paper presents the methodology, and the second discusses the results and the conclusions of the investigation conducted in the City Library in Zadar. This Library was chosen for the two main reasons, the first was the announcement that the Library needed an extension, and the second was the fact that the need for the new library space for young adults was recognized both by the librarians and by the city policy and decision makers.

The first research goal was to see and describe the young adults' reactions after seeing the visual presentations of various library buildings. The second goal was related to expressing their own views about their needs when it comes to adapting the existing library space and introducing new activities, using the available areas for the extension of the City Library in Zadar. Their attitudes concerning organization and design of the space were also investigated. The third goal was to identify the attitudes of the professionals working with young adults about the library space for young adults, its design and furnishing. 
The assumptions of the research were that young adults desire their own library space and that they have ideas about how to organize and design it, and also that the professionals working with young adults expect that the City Library would attract more users if the attractive, functional and pleasant premises were offered.

The research was based on the use of the qualitative methodology (focus-groups and interviews) and was conducted in 2015.

The research results showed that all respondents were aware of the need for new, attractive, functional, and pleasant premises which would enable the library to offer a number of new services for young adults.

Keywords: young adults, library architecture, youth library

\section{Uvod}

Mladi su osobe na razmeđu djetinjstva i odrasle dobi sa svojim specifičnim potrebama, poglavito $\mathrm{u}$ današnje vrijeme kad im se nude raznoliki izvori i komunikacijski kanali. U području knjižničarstva autori nejednako određuju dob mladih korisnika (uglavnom između 12 i 19 godina) i pritom koriste različito nazivlje, naprimjer tinejdžeri, mladi odrasli, adolescenti. Dobni raspon te populacije ovisi o zemlji i kulturi, pa knjižnice često samostalno određuju raspon koji obuhvaća mladalačku dob, odnosno na koga će se sve odnositi usluge namijenjene mladoj populaciji. ${ }^{2}$ Usto, mladi su različitih svjetonazora, pripadaju različitim kulturama, imaju različite intelektualne sposobnosti i slično, o čemu detaljno govore i IFLA-ine Smjernice za knjižnične usluge za mladež. ${ }^{3} \mathrm{U}$ tom se dokumentu ističe i važnost izdvojenih posebnih prostora za mlade s ciljem da se u pažljivo osmišljenim i privlačnim prostorima ugodnije osjećaju i da budu potaknuti na rad i daljnje obrazovanje primjereno njihovoj dobi. ${ }^{4}$

Mladima kao korisničkoj skupini u knjižnicama sve donedavna nije posvećivana dostatna pažnja. Zanimanje za mlade kao posebnu korisničku skupinu u narodnim knjižnicama javlja se relativno kasno. U Sjedinjenim Američkim Državama (SAD) početkom prošlog stoljeća vodile su se rasprave o uslugama za mlade, kao i o prostoru za mlade, što je potaknulo knjižnice na objavljivanje

2 Usp. naprimjer Stričević, Ivanka; Srećko Jelušić. Knjižnične usluge za mlade: modeli i koncepti. // Vjesnik bibliotekara Hrvatske 53, 1(2010), str. 5-6; Stropnik, Alka. Knjižnica za nove generacije: virtualni sadržaji i usluge za mlade. Zagreb : Hrvatsko knjižničarsko društvo, 2013.; Schmitt, Rita. Novi koncepti za knjižnice za mladež. Zagreb : Goethe Institut, 2001. [citirano: 2015-07-31]. Dostupno na http://www.goethe.de/mmo/priv/568480-STANDARD.pdf.

3 Usp. Smjernice za knjižnične usluge za mladež: prerađeno izdanje Smjernica koje je 1996. objavio Stalni odbor Selekcije knjižnica za djecu i mladež / priređivači: Pat Muller i Ivan Chew. Zagreb : Hrvatsko knjižnično društvo, 2009. Str. 12.

4 Usp. isto, str. 15. 
stručnih radova na tu temu. ${ }^{5}$ Jedan od razloga zanemarivanja mladih kao korisnika knjižničnih usluga bila je dugogodišnja tradicionalna podjela knjižnica na odjele za odrasle i dječje odjele. Gotovo bez iznimke, aktivnosti i programi vezivali su se uz dječje odjele, što se može jasno vidjeti i u domaćoj praksi devedesetih godina prošlog stoljeća ${ }^{6}$, kao i u drugim sredinama u kojima su brojne narodne knjižnice pokrenule raznovrsne programe za rad s mladima. Nove tehnologije, globalizacija i novi načini komuniciranja omogućili su dostupnost i razmjenu informacija na svakom koraku, a nove vrste pismenosti mijenjaju navike mladih. Osim toga, mladi su danas podložni brzom prihvaćanju trendova i ranijem sazrijevanju, unatoč sve snažnijem trendu ekonomske ovisnosti o roditeljima. ${ }^{7}$ Prema podacima iz Smjernica za knjižnične usluge za mladež, mladi kao korisnička skupina predstavljaju četvrtinu korisnika narodne knjižnice. ${ }^{8}$

Najviše iskustva s knjižničnim uslugama za mlade u narodnim knjižnicama, kako su u svom preglednom radu istaknuli I. Stričević i S. Jelušić, imaju knjižnice u razvijenim sredinama, poglavito u SAD-u i Republici Njemačkoj, u kojima se provodi i najveći broj istraživanja o mladima kao korisnicima i potencijalnim korisnicima knjižničnih usluga. Rezultati tih istraživanja i primjeri dobre prakse predstavljaju se međunarodnoj knjižničnoj zajednici s ciljem širenja ideje da narodne knjižnice moraju prepoznati mlade kao posebnu korisničku skupinu. ${ }^{9}$

Sa stajališta organizacije knjižničnih službi i usluga u narodnoj knjižnici, Stričević i Jelušić izdvajaju tri osnovna koncepta: knjižnicu za mlade, odjel za mlade i program za mlade. ${ }^{10}$

Koncept knjižnice za mlade odlikuje poseban izdvojen prostor narodne knjižnice koji djeluje kao samostalni ogranak. Primjeri takvih knjižica su Knjižnica za mlade u Dresdenu, Knjižnica za mlade u Hamburgu i Knjižnica za mlade Gradske knjižnice „I. G. Kovačića“ u Karlovcu. ${ }^{11}$

Odjel za mlade sastavni je dio narodne knjižnice, a odlikuje ga smještaj posebnih usluga i službi za mlade. Važno je istaknuti kako je takav odjel samostalan,

\footnotetext{
5 Usp. Stričević, Ivanka; Srećko Jelušić. Nav. dj., str. 7-9.

6 Usp. Standardi za narodne knjižnice u Republici Hrvatskoj. // Narodne novine 58, 1071(1999). [citirano: 2015-08-09] Dostupno na http://narodne-novine.nn.hr/clanci/sluzbeni/270810.html.

7 Usp. Lammiman, Jean; Michel Syrett. Cool generacija: nova poslovna filozofija. Zagreb : Naklada Ljevak, 2005.

8 Usp. Smjernice. Nav. dj., str. 12.

9 Usp. Stričević, Ivanka; Srećko Jelušić. Nav. dj., str. 7-9.

10 Usp. isto, str. 18.

11 Valja naglasiti da je u Zagrebu 2000. godine otvoren prvi posebni odjel za mlade u Knjižnici Medveščak, a da je 2003. otvorena i prva Knjižnica i čitaonica za mlade pri Gradskoj knjižnici „Ivan Goran Kovačićc u Karlovcu.
} 
odnosno nije sastavni dio odjela za djecu ili odjela za odrasle. U praksi, odjeli za mlade najčešće se javljaju u njemačkim narodnim knjižnicama, a u Hrvatskoj ima nekoliko primjera takvih odjela, poput Odjela za mlade u Knjižnici „Metel Ožegović“ u Varaždinu, Odjela za mladež u Knjižnici Ante Kovačića u Zaprešiću ili Odjela za mladež u Knjižnici Medveščak (Knjižnice Grada Zagreba).

Kad se pak govori o konceptu programa za mlade, misli se na posebne programe koji su namijenjeni mladima, poput npr. programa u gradskim knjižnicama u Rijeci, Zadru i Čakovcu. Programi za mlade provode se u sklopu postojećih odjela narodne knjižnice, odnosno odjela za djecu i odjela za odrasle. Taj koncept ima najdulju tradiciju u praksi. ${ }^{12}$

U svim poznatim pristupima i modelima prostor je jedan od temeljnih preduvjeta, ali i jedna od nezaobilaznih prepreka u osmišljavanju i provođenju inovativnih programa za mlade. U ovome radu posebno nas zanima model knjižnice za mlade postavljene u zaseban, pomno osmišljen prostor slijedom ideja i prijedloga samih mladih korisnika knjižnice. U takvoj knjižnici službe i usluge smještaju se u poseban prostor u kojemu se nalaze posebne zbirke knjižnične građe za mlade, provode aktivnosti s mladima i djeluje osoblje kompetentno za rad s mladima. Slijedom preporuka iz Smjernica za knjižnične usluge za mladež, prostori namijenjeni mladima trebaju osigurati slobodan pristup internetu, ponuditi referentne informacije koje mladim ljudima pomažu u učenju i osobnom razvoju, ponuditi programe za informatičko, informacijsko i medijsko opismenjavanje, za što treba osigurati odgovarajuće prostore (učionice, multimedijalne kutke i slično), savjetodavnu službu (pojedincima i skupinama) u izdvojenim prostorima kako bi se osigurala privatnost i steklo povjerenje mladih te druge usluge za koje treba osmisliti i prostor i primjerenu opremu. Usto, preporuča se organizirati obilaske knjižnice s ciljem prevladavanja nesigurnosti u kretanju i korištenju knjižnicom te oblikovati interijer na način da se mladi osjećaju dobrodošlo i ugodno. ${ }^{13}$

Važno je istaknuti da u literaturi o knjižničnoj arhitekturi ne nalazimo posebno elaborirane zahtjeve za prostorima i oblikovanjem prostora za mlade sve do konca 20. stoljeća. Čak i nezaobilazni i cijenjeni priručnik Godfreya Thompsona o planiranju i dizajniranju knjižničnih zgrada (1989. i njegova kasnija izdanja) ${ }^{14}$ ni na jednom mjestu ne spominje mlade niti govori o specifičnostima prostora i mogućim aktivnostima koje bi mladima približile knjižnicu kao mjesto susreta i ugode. U arhitektonskim časopisima nailazimo u posljednje vrijeme na informacije o novim odjelima za mlade, posebnostima pojedinih rješenja i nagrađenim

12 Usp. Stričević, Ivanka; Srećko Jelušić. Nav. dj., str. 7-9.

13 Usp. Smjernice. Nav. dj. i Schmitt, Rita. Nav. dj.

14 Thompson, Geodfrey. Planning and design of library buildings. London: Butterworth Architecture, 1989. 
radovima (usp. naprimjer časopise Canadian Architecture ${ }^{15}$, Architecture Australia ${ }^{16}$, Architectural Record ${ }^{17}$, E-architect ${ }^{18}$ ). Novi pristupi rješavanju problema mladih uključuju i aktivnosti izvan knjižnica, poput lokalnih centara za mlade čiji je cilj privući mlade na različite aktivnosti, osobito u dijelovima gradova koji su zapušteni ${ }^{19}$ ili u gradskim središtima koja se nastoje revitalizirati ${ }^{20}$, što također nameće potrebu iznalaženja valjanih prostornih rješenja.

Što se tiče uključivanja mladih u oblikovanje njima namijenjenih prostora, $\mathrm{u}$ literaturi je pronađen primjer suradnje studenata arhitekture i djece na preoblikovanju dječjeg odjela ${ }^{21}$ te članak o otvorenju novog odjela za mlade u Narodnoj knjižnici u Dunedinu, Novi Zeland, u kojem autorica predstavlja cjelovit postupak osmišljavanja koncepta usluga za mlade, a što je uključilo i konzultacije s većim brojem mladih. Naglasila je da su mladi imali odlučujuću ulogu u osmišljavanju prostora i budućih aktivnosti. ${ }^{22}$

Pošavši od stajališta prema kojem je važno prihvatiti da mladi najbolje znaju što im je privlačno, zanimljivo i korisno te da su stručnjaci koji rade s mladima otvoreni za suradnju s mladima, autorice su odlučile provesti istraživanje u Gradskoj knjižnici Zadar koja uporno nastoji proširiti svoj sadašnji prenapučen prostor i koja planira izdvojiti i opremiti prostor za mlade unutar nove zgrade namijenjene proširenju sadašnje knjižnice..$^{23}$

\footnotetext{
15 Usp. Canadian Architecture. [citirano: 2015-04-21]. Dostupno na https://www.canadianarchitect.com/.

16 Usp. Architecture media. [citirano: 2015-04-21]. Dostupno na https://architecturemedia. com/magazines/architecture-australia/.

17 Usp. Architectural Record. [citirano: 2015-04-21] Dostupno na http://www.architecturalrecord.com/.

18 Usp. E-architect. [citirano: 2015-04-21]. Dostupno na https:/www.e-architect.co.uk/.

19 Naprimjer Whitehead, Terri. Community action. // Canadian Architecture, 1(2005), 20-24.

20 Naprimjer Harding, Laura. Narellan Library. // American Architecture (May-June 2006), 8086.

21 Usp. Lozanovska, Mirjana ; Leilei Xu. Children and university architecture students working together: a pedagogical model of children's participation in architectural design. // CoDesign 9, 4(2013), 209-229. [citirano: 2015-10-21]. Dostupno na http://dx.doi.org/10.1080/15710882.20 12.693187.

22 Usp. Ikin, Su. Our library their space: The Dunedin City Library teen space. // Aplis 23, 2(June 2010), 61-66.

23 Već nekoliko godina naime traju pregovori s Gradom Zadrom da se Gradskoj knjižnici ustupi dio zgrade koja se nalazi tik uz sadašnju knjižnicu, a u koju Grad želi smjestiti i neke druge udruge koje se bave mladima.
} 


\section{Opća načela arhitekture i prostori za mlade}

Uvođenjem i primjenom novih građevinskih tehnologija i materijala otvorene su mogućnosti za osmišljavanje i gradnju novih građevinskih oblika za potrebe knjižnica. Odraz tih inovacija razvidan je u narodnim knjižnicama u Francuskoj, Engleskoj, Njemačkoj i Americi ${ }^{24}$ te u nekim drugim sredinama poput naprimjer Australije, Portugala ili Slovenije. Jedno od temeljnih načela pritom je prilagodljivost prostora zbog stalnih mijena u vrsti i načinu ponude usluga. Dakako, knjižnični prostori i nadalje teže kvalitetnom i funkcionalnom načinu oblikovanja kako bi se ispunili arhitektonski i estetski kriteriji. Knjižnične zgrade slijede već više od pola stoljeća poznate Faulkner-Brownove „zapovijedi““25 koje su primjenjive i u odnosu na cjelovitu knjižničnu zgradu i u odnosu na izdvojene dijelove unutar zgrade, poput odjela za mlade.

Općenito uzevši, unutar knjižničnog prostora, načelo funkcionalnosti temelj je nastojanja da se određeni prostor može izgledom, strukturom i uslugom lako prilagoditi promjenjivim zahtjevima iz okruženja, pa tako i potrebama mijenjanja rasporeda slijedom novih načina komuniciranja, što je kod mladih izrazito važna pretpostavka. Načelo kompaktnosti zagovara lakoću kretanja korisnika, osoblja i knjižnične građe, a načelo pristupačnosti nalaže da se iz okoliša u zgradu i s ulaza u sve dijelove zgrade može pristupiti slijedom jednostavnog plana koji zahtijeva minimum oznaka za snalaženje. Ta načela primjenjiva su u velikoj mjeri na oblikovanje prostora za mlade, poglavito sa stajališta privlačenja u knjižnicu i olakšavanja snalaženja. Načelo raznolikosti, koje se odnosi na osiguravanje smještaja građe i usluga korisnicima kako bi im bila pružena sloboda izbora, posebno je važno u odjelima za mlade zbog njihova osjećaja da sami trebaju odabirati što ih zanima, kad ih zanima i u kojim sve izvedbenim inačicama. Potrebe da se postigne osjećaj udobnosti i privlačnosti svjesni su i mladi i knjižničari, koji time nastoje poticati jednostavnost i lakoću upotrebe. ${ }^{26}$

U odnosu na dizajn narodne knjižnice vrijedno je istaknuti opća načela dizajna koja su se pokazala nezaobilaznima u postizanju sklada između funkcionalnosti i estetike. To su načelo biofilijskog efekta, efekta katedrale, načelo pažljivog oda-

\footnotetext{
24 Usp. Edwards, Brian. Libraries and learning resource centres. 2nd ed. Amsterdam ; London : Architectural Press, 2009. Str. 47.

25 Usp. Faulkner-Brown, Henry. Some thoughts on the design of major library buildings. // Intelligent library buildings: Proceedings of the 10th Seminar of IFLA's Library Buildings and Equipment Section / edited by Marie-Françoise Bisbrouck and Marc Chauveinc. The Hague, Netherlands, 1997 1997. Str. 14-26.

26 Ostala načela ne odnose se izravno na mlade, pa ih ne navodimo, ali valja naglasiti da se radi o načelima o kojima knjižnica unutar koje se smješta odjel za mlade itekako mora voditi računa (naprimjer načelo proširivosti, načelo organiziranosti mikroklimatskih uvjeta, načelo sigurnosti). Usp. isto.
} 
bira i sklada boja, vrste struktura i načelo simetrije ${ }^{27}$, za koja se drži da posebno utječu na korisnike mlade dobi.

Razmišljajući o navedenim načelima dizajna u kontekstu oblikovanja prostora za mlade, autorice su nastojale dovesti u odnos svako načelo s ponašanjem, odnosno potrebama mladih. Tako se biofilijski efekt, zasnovan na biofilijskoj hipotezi koju je prvi put predstavio Erich Fromm, a popularizirao Edward Wilson, postiže pažljivim uklapanjem zgrade u okoliš, odnosno interpolacijama elemenata iz prirode u zgradu, kako bi se obogatili pogledi na prirodu i prizore iz prirode, smanjio stres i poboljšala usredotočenost i koncentracija. Upotreba tog efekta preporuča se u prostorijama za učenje. ${ }^{28}$ Efekt katedrale postiže se odnosom između visine stropa i mentalnih procesa, a primjenjiv je kad se nastoji postići kreativnost i razmišljanje, što je posebno važno kod mladih osoba. Boja se u dizajnu uobičajeno koristi za privlačenje pozornosti, grupiranje elemenata, prenošenje značenja i unapređivanje estetskog dojma, pa je nezaobilazna pri uređivanju prostora za mlade kako bi im vizualno bili zanimljivi i privlačni. Vrste pak strukturâ i simetričnost, svojstva su za postizanje vizualnog sklada među elementima unutar knjižnice slijedom njihovih različitih namjena. Osim estetskih svojstava, simetrični oblici doživljavaju se kao likovi, a ne kao pozadina. U dizajnu, simetrija se koristi za oblike koji su važni za prepoznavanje i prisjećanje, dok se složenije kombinacije simetrija koriste kad su estetski važni i zanimljivi.

Ništa manju ulogu ne igra ni oprema u prostorima namijenjenim mladim korisnicima, jer je nužna u svim fazama njihova korištenja knjižnicom (npr. učenje, zabava, rasprave, projekti, programi). Uređenje prostora za mlade velik je izazov jer zahtijeva takve pristupe koji će omogućiti da se uz knjižničnu građu na različitim medijima ukomponiraju svi uređaji i oprema koja zanima mlade i koja im je potrebna za kreativno djelovanje, učenje i razonodu. Pritom nije naodmet istaknuti da su sâm prostor i njegova udobnost važniji od veličine. Prostor bi trebao biti udoban, privlačan, pozivati na druženje, učenje i zabavu. Osim te namjene, prostor treba biti prepoznatljiv i tako da ga se dobro vizualno označi radi lakšeg snalaženja. Kako sugerira poznata stručnjakinja za rad s mladima Verena Tibljaš, pri vizualnom obilježavanju poželjno je koristiti terminologiju blisku mladima i dopustiti mladima da sudjeluju u oblikovanju prostora i signalizacije. ${ }^{29}$

Općeprihvaćeno je motrište prema kojem izbor namještaja čini prostor ugodnim i poželjnim. S obzirom na to da mladi često dolaze u skupinama, za njih

27 Usp. Lidwell, William; Kristina Holden; Jill Butler. Univerzalna načela dizajna. Zagreb : Mate, 2013. Str. 36.

28 Usp. isto, str. 38, 48, 234.

29 Usp. Tibljaš, Verena. Kako izgleda dobra narodna knjižnica za mlade. // Slobodan pristup informacijama : 7. i 8. okrugli stol : zbornik radova / urednice Aleksandra Horvat i Loris Bučević Sanvincenti. Zagreb: Hrvatsko knjižnično društvo, 2009. Str. 146-151. 
knjižnica postaje više od mjesta za posudbu knjige i drugih medija - knjižnica je mjesto zajedničkog boravka, zajedničkog korištenja medija i komuniciranja. U tu svrhu arhitektonska i dizajnerska načela sugeriraju funkcionalan namještaj kao važan čimbenik samog ambijenta knjižnice.

\section{Istraživanje potreba mladih u Gradskoj knjižnici Zadar}

Gradska knjižnica Zadar javna je institucija na usluzi svojim korisnicima od 1949. godine, a jedan od njezinih poznatijih i vrlo posjećenih odjela jest Dječji odjel. Do danas međutim odjel za mlade nije osnovan, ali se niz programa za mlade odvija unutar prostora Dječjeg odjela, što je, uostalom, kako smo ranije istaknuli, bila i jest česta pojava u mnogim narodnim knjižnicama. Dječji odjel Gradske knjižnice u Zadru posjeduje fond u kojem se nalaze slikovnice za najmlađe, lijepa književnost za djecu i mlade, stripovi, knjige za roditelje, odgajatelje, učitelje, popularno-znanstvena literatura za djecu i mlade, priručna literatura, časopisi, igračke, društvene igre itd. Osim bogatog fonda, Odjel pruža raznovrsne usluge $\mathrm{i}$ organizira brojne aktivnosti poput radionica za djecu, čitateljskog kluba za mlade od 13 do 15 godina te „Svaštarnice“ - programa koji omogućuje druženje mladih, a koji usmjeravaju mladi knjižničari. ${ }^{30}$

Za ovo istraživanje Gradska knjižnica Zadar odabrana je i stoga što se najavljuje njezino proširenje i što je među knjižničnim djelatnicima i pojedincima iz lokalne samouprave prepoznata potreba da se mladima osigura poseban prostor. Naime unatoč tomu što je Zadar uspio izgraditi i opremiti jednu od najfunkcionalnijih hrvatskih narodnih knjižnica, unutar postojećeg knjižničnog prostora nije bilo moguće smjestiti poseban prostor za mlade, pa su posljednjih godina učestali zahtjevi za takvim prostorom, a sami knjižničari nastoje pronaći optimalno rješenje za proširenje sada već, sasvim očito, prenapučene knjižnice. Na tragu tih saznanja osmišljeno je i provedeno istraživanje čije najvažnije rezultate predstavljamo u ovome radu.

\subsection{Istraživačka metodologija}

Svrha je istraživanja bila utvrditi osnovna polazišta za oblikovanje i opremanje Knjižnice za mlade u Zadru polazeći od stavova ispitanika.

\footnotetext{
30 U Središnjoj knjižnici čitateljski klub za mlade djeluje pod nazivom Dioptrija i održava se od ožujka 2009. godine svake prve srijede u mjesecu. Sastanke moderira urednica portala eZadar, koja se u projekt uključila volonterski. Klub čitatelja za mlade u ogranku Bili brig održava se jednom mjesečno pod vodstvom jedne srednjoškolske profesorice i volonterke Gradske knjižnice Zadar. Usp. Gradska knjižnica Zadar. [citirano: 2015-10-15]. Dostupno na http://www.gkzd. $\mathrm{hr} /$ ?q=hr/djecji.
} 
$\mathrm{Na}$ tom tragu postavljeni su i ciljevi istraživanja. Pošavši naime od zatečenog stanja i evidentnog zanimanja određenog broja mladih za programe i aktivnosti koji se za njih osmišljavaju i nude te mogućeg projekta širenja Gradske knjižnice Zadar koji bi uključio i prostore za mlade, prvi je istraživački cilj bio utvrditi kako mladi reagiraju na predstavljene vizualne prikaze knjižnica koji su odabrani kao primjeri dobre prakse, a drugi je cilj bio usmjeren prema iskazu njihovih vlastitih potreba za mogućim prostorom i aktivnostima u potencijalno raspoloživom prostoru za širenje sadašnje knjižnice te prikupljanju stavova o organizaciji i uređenju novog prostora. Treći je cilj istraživanja bio utvrditi stavove knjižničara i stručnjaka koji rade s mladima u odnosu na prostore za mlade, njihovo oblikovanje i opremanje.

U ovom se istraživanju pošlo od sljedećih pretpostavki:

- da mladi žele svoj prostor i da imaju jasne ideje o tome kako taj prostor urediti

- da knjižničari očekuju da bi se u knjižnicu mogao privući veći broj mladih ako bi njima namijenjen prostor bio privlačan, funkcionalan i ugodan.

Istraživanje je provedeno tijekom 2015. godine primjenom kvalitativne metode istraživanja uz uporabu instrumenta fokus-skupine i intervjua. Fokus-skupina kao metoda odabrana je jer se pokazala kao vrijedna kvalitativna istraživačka metoda koja omogućuje da ispitivači kao moderatori prate i proučavaju ispitanike u njima prirodnom okruženju. U takvim skupinama ispitivač kao moderator može potaknuti sudionike da otvoreno rasprave svoja mišljenja i prijepore vezane uz odabranu temu, a ispitanici mogu lakše i jasnije izraziti osobne doživljaje $\mathrm{i}$ iskustva. ${ }^{31} \mathrm{U}$ fokus-skupinama sudjelovalo je ukupno 12 ispitanika (mladih korisnika) u središnjoj knjižnici i u ogranku Bili brig. Fokus-skupina u središnjoj knjižnici sastojala se od osam sudionika u dobi od 12 do 17 godina (svi korisnici dječjeg odjela Gradske knjižnice Zadar). Kako bi se sudionici osjećali ugodnije, razvrstani su u dvije skupine od po četiri ispitanika. Vrijeme održavanja fokus-skupine bilo je 23. srpnja 2015. u trajanju od jednog sata, a u provedbi je pomagala knjižničarka s tog odjela. Fokus-skupina u ogranku Bili brig sastojala se od četiri sudionika u dobi od 14 do 17 godina (korisnice Gradske knjižnice Zadar). Istraživanje je provedeno 6. studenog 2015. godine u trajanju od jednog sata.

Istraživačkim pitanjima nastojalo se utvrditi (1) kako se mladi osjećaju u prostorima koji su im na raspolaganju; (2) ima li prema njihovu mišljenju do-

31 Usp. Zrile, Marina; Dina Vozab; Mladen Blagojević. Pribor za prvu pomoć za visoko obrazovanje. [citirano: 2015-05-21]. Dostupno na

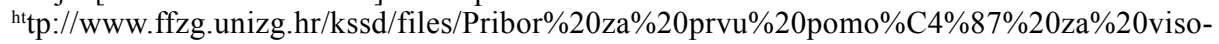
ko\%20obrazovanje.pdf. 
voljno prostora za učenje i druženje; (3) jesu li upoznati s konceptom odjelâ, odnosno knjižnica za mlade; (4) kako gledaju na ideju odvojenog prostora za svoje aktivnosti te (5) kako vizualno doživljavaju građevine i namještaj koji ima netipičan izgled. Razgovor unutar fokus-skupina vođen je kroz tri cjeline: raspravu o pripremljenim slikovnim prilozima, raspravu o ponuđenom prijedlogu moguće prostorne organizacije odjela za mlade te kroz izlaganje prijedloga samih ispitanika.

Za prvi dio rasprave priređena je PowerPoint-prezentacija sa slikovnim prilozima koje su pratila unaprijed pripremljena pitanja. Cilj je bio potaknuti znatiželju i reakcije sudionika na pojedino obilježje prostora ili opreme. Tijekom prezentacije prikazane su 22 slike s istaknutim različitim elementima i obilježjima, uz popratna pitanja uz svaku prikazanu sliku kojima se nastojalo izazvati reakcije vezane uz doživljaj pojedinog prikazanog objekta. Odabrane slike u prezentaciji prikazivale su vanjski izgled knjižnica, primjere uređenja prostora za učenje, kreativne radionice i druženje te višenamjenski namještaj. Odabrane su slike $u$ rasponu od običnog i monotonog do veselog i šarolikog izgleda pojedinog objekta prikazivanja kako bi se saznalo što se mladima više sviđa.

Ponuđenim prijedlogom organizacije prostora za mlade unutar četiriju prostornih cjelina (prostor za učenje, prostor za susrete, inspirirajući prostor i prostor za aktivnosti) nastojalo se saznati jesu li ispitanicima te cjeline prihvatljive. Naposljetku, kroz zaključni dio razgovora unutar fokus-skupina nastojalo se saznati imaju li ispitanici druge ideje i prijedloge i kako bi uredili interijere tih prostora.

Intervjui su vođeni s knjižničarima koji rade s mladima. Razgovori su usmjeravani uz pomoć unaprijed pripremljenih pitanja koja su bila organizirana unutar nekoliko cjelina. Prva se cjelina odnosila na opće podatke te stavove ispitanika o mladima kao korisničkoj skupini i njihovim potrebama za informacijama, građom i drugim uslugama. U odnosu na žarište istraživanja - prostor za mlade - razgovor je imao za cilj saznati je li Dječji odjel prilagođen mladima te trebaju li mladi imati odvojen prostor za sebe. Ako bi se radilo na proširenju zgrade i oblikovanju posebnog prostora za mlade, zanimalo nas je što ispitanici misle o temeljnim obilježjima tog prostora, kako bi trebale izgledati pojedine njegove cjeline i o kojim bi se sve aktivnostima radilo, odnosno koje bi se nove usluge mogle pružati. Naposljetku, zanimalo nas je mišljenje ispitanika o tome tko je ključan čimbenik realizacije ideje o prostoru za mlade unutar Gradske knjižnice u Zadru. Intervjui s pet osoba koje rade s mladima, a pristale su sudjelovati u istraživanju, provedeni su 31. listopada 2015. godine (ispitanik - I1) i (ispitanik - I3), 3. studenog 2015. godine (ispitanik - I4) i (ispitanik - I2) te 6. studenog 2015. godine (ispitanik I5). Među ispitanicima tri su knjižnična djelatnika (I1, I2 i I3) i dvije volonterke (I4, I5). Intervjui su trajali između 50 i 60 minuta. 


\subsection{Rezultati i rasprava}

\subsubsection{Fokus-skupine}

Upitani koliko često posjećuju knjižnicu, svi su ispitanici naglasili da posjećuju jednu ili drugu knjižnicu, čineći to ponekad češće, a za vrijeme školske godine rjeđe zbog drugih obveza - dakle bilo je očito da su dobro upoznati s prostorom i ponudom usluga.

Komentirajući prikazane slike, sudionici su pokazali zanimanje za zgrade i unutarnje uređenje knjižnica, a svoja su zapažanja iznosili uz svaki ponuđeni primjer. Za pročelje zgrade jednog knjižničnog ogranka (Jasper Place Branch Library, Kanada), koje je odabrano zbog zanimljive valovite strukture, sudionici fokus-skupine smatrali su da je jako privlačno, neobično i da im se vrlo sviđa. Slijedile su slike australske knjižnice (Green Square Library u Sidneyu) koja je dobila priznanje za usklađenost s okolišem, vanjski izgled regionalne otočne knjižnice (Vancouver Island Regional Library, Kanada) kao primjer moderne arhitekture $\mathrm{s}$ vrlo strogim oblicima te crteži na pročelju narodne knjižnice u Mexico Cityu. Slika australske knjižnice koja je prikazivala modernu zgradu na stupovima okruženu uređenim okolišem kod ispitanika je izazvala oduševljenje, a vankuverska knjižnica nije prihvaćena s odobravanjem jer ih je pročelje zgrade više podsjećalo na banku nego na knjižnicu.

Slike koje prikazuju staklene viseće biljke u jednoj knjižnici i jednom trgovačkom centru ukazivale su na nastojanje da se modernom arhitekturom postigne biofilijski efekt, što je kod sudionika izazvalo nepodijeljeno odobravanje. Iskazali su stav da je priroda inspirativna i da djeluje opuštajuće.

Na slikama koje su prikazivale korisnike u prostorima za druženje koji su uređeni tako da na stepenicama imaju meke podloge za sjedenje, dok se u ostalom dijelu prostora nalaze stolice te prikazom interijera u bijeloj i plavoj boji sudionike se željelo potaknuti na raspravu o tim prostorima, njihovu uređenju i primjeni boja. Gotovo bez iznimke ispitanici su potvrdili da bi željeli takva rješenja jer su i inače stepenice njihovo omiljeno mjesto za sjedenje. Odabrani su i primjeri interijera namijenjeni učenju uz osiguranu privatnost, korištenje stepenica za sjedeća mjesta te rješenja za smještaj računala. Naposljetku, na nekoliko su slika prikazani višenamjenski namještaj i inovativna rješenja za smještaj namještaja i opreme. Na sve su slike sudionici reagirali u rasponu od oduševljenja do iskaza nezadovoljstva kad se radilo o neobičnim konstrukcijama ili monotonim bojama.

Tako su tijekom provođenja istraživanja sudionici fokus-skupine zamoljeni da razmisle i komentiraju ponuđeni prijedlog organizacije prostora za mlade unutar četiriju cjelina - prostora za učenje, prostora za susrete, inspirirajućeg prostora koji pruža pristup knjižničnoj građi i prostora za aktivnosti - te da iznesu vlastita zapažanja i sugestije. 
Složili su se da treba osigurati prostor za učenje čija bi namjena bila otkrivanje i stjecanje novog znanja kroz tečajeve, radionice, mogućnosti e-učenja i pisanje domaće zadaće, kao i prostor za susrete namijenjen korisnicima u skupinama kako bi se mogli družiti i održavati rasprave (,parlaonice“) o aktualnim temama. Naglasili su važnost organizacije i uređenja prostora kako bi on djelovao inspirirajuće te olakšavao i poticao pristup knjižničnoj građi, umjetničkim radovima, filmskim i glazbenim materijalima, računalima, društvenim igrama i slično. Za radni prostor, namijenjen maštovitim, kreativnim aktivnostima koje izvode korisnici kroz tematski osmišljene likovne radionice, dramske, filmske, glazbene, plesne radionice te radionice kreativnog pisanja, istaknuli su da treba biti fleksibilan, različitih radnih površina i višebojan.

Nakon prikazanih slika i reakcije sudionika fokus-skupina, razgovor je nastavljen na osnovi pitanja koja su imala za cilj saznati nešto o samim mladim korisnicima, njihovim navikama i potrebama u odnosu na informacije i građu, sadržajima koji su vezani uz njihovo učenje, kreativno izražavanje i zabavu te stajalištima o prostoru koji trenutno koriste unutar knjižnice.

Tijekom razgovora s fokus-skupinama zabilježeni su sljedeći stavovi i prijedlozi sudionika:

- Vezano uz funkcionalnost postojećeg Dječjeg odjela i usluga koje im se pružaju, sudionici su izrazili zadovoljstvo uslugama, a manje zadovoljstvo radnim prostorom. Naime ukazali su na to da ponekad nema dovoljno radnih površina na odjelu, što ih primorava na korištenje drugih prostora u knjižnici, poput Odjela za odrasle, gdje se ne osjećaju ugodno.

„Tamo na odraslom se ne mogu snaći, ima dosta čudnih naslova.

Nađem jedan pa se ne mogu snaći dok je ovdje lakše.“

- Vezano uz nužnost da prostor dijele s djecom, ispitanici uglavnom ne nalaze da ih djeca ometaju jer su odrastali s njima i jer je prostor za djecu ipak odvojen namještajem i igračkama.

„Mislim da je ok jer su djeca na jedan način odvojena s igračkama, ako ne, ima stolova sa strane. Naviknuli smo na ovaj prostor."

- U odnosu na nedostatak prostora za učenje, ispitanici smatraju da je Dječji odjel prihvatljiv za učenje kad nema mnogo buke, mada su naučili kako se izolirati za vrijeme učenja.

„Je, je, kad nema previše dječje vriske, onda se može čak i skoncentrirati. Meni osobno to i ne smeta jer sam se ja naučila isključiti.“ 
- U odnosu na pretpostavku da mladi ispitanici nisu do samoga istraživanja znali da postoje knjižnice ili odjeli za mlade, dokazano je da se sudionici nikad nisu osvjedočili o postojanju odjela za mlade ili knjižnice za mlade.

- U ogranku Bili brig, prostor namijenjen djeci i mladima je premalen. Budući da ga koriste i djeca i mladi, ponekad se korisnici ne osjećaju ugodno, osobito mlađi korisnici.

- Novi mediji ispitanicima su svakako poželjni jer su im oni sastavni dio života te su neophodni za učenje i izradu domaćih zadaća.

„Kompjutera bi trebalo biti u knjižnici jer to pomaže u izradi nekih radova što se ne može naći u knjizi. Možda čak ne previše jer se može naći na toj Wikipediji. Ne treba ih sad puno, možda dva ili tri."

„Volim te tehnološke stvarčice, definitivno ne bih mogla bez kompjutera, laptopa, to mi je ono nužno za svaki dan, ali nisam fan za čitanje na tabletima. Sporije mi dosta ide i zamara mi oči nekako više, ali čitam na tabletu ili kompjuteru jedino ako baš ne mogu nigdje naći lektiru u knjižnici pa ju nađem na internetu u pdf-u, ali mislim da bi trebalo biti definitivno za mlade.“

Nakon spoznaje o postojanju posebnog prostora za mlade i knjižnice za mlade s prikaza u PowerPoint-prezentaciji, njihovih komentara ponuđenog prijedloga i iznošenja vlastitih iskustava vezano uz korištenje Dječjeg odjela, sudionici su zamislili i predložili moguća idejna rješenja za određene prostore. Unaprijed pripremljena pitanja imala su za cilj to da sudionici izdvoje što im je najvažnije u prostoru za učenje, a što u prostoru za susrete/druženje te čemu pridaju najveću pozornost u prostoru namijenjenom za pregledavanje knjiga i radnom prostoru.

Utvrđeno je da im je u prostoru za učenje važan mir, tišina, dovoljno svjetla, dostupnost interneta, a u prostoru za susrete poželjno je dobro društvo, dovoljno sjedećih mjesta, prostranost, ugodan namještaj i urednost. U prostoru za smještaj knjiga istaknuli su važnost rasporeda knjiga, ugodan namještaj, ugodne boje prostora te urednost, a u prostoru za korisnike važan im je dovoljan broj sjedećih mjesta, urednost stolova te tišina u prostoriji.

Prostor za učenje prema njihovu bi mišljenju trebao biti jednostavan, s minimalnim brojem popratnih stvari (posteri, biljke itd.), raznobojan i s mnogo radnih površina. Isticali su kutke u kojima su vidjeli korisnike kako se druže, uče ili rade na računalima koja su izdvojena pregradama, što osigurava privatnost. Jedan od primjera privatnosti tijekom čitanja jesu police koje imaju predviđeno mjesto za čitanje: „Super mjesto kad uzmem knjigu za čitati.“

Ispitanici su isticali potrebu za prostorima za druženje koje bi smjestili što bliže prozoru te oslikali veselim bojama na zidovima i namještaju. Smatrali su da 
bi odjel za mlade trebao biti prostran i dobro osmišljen za održavanje raznih aktivnosti, poput likovnih, putopisnih ili književnih. Sâm izgled odjela ili knjižnice za mlade trebao bi biti neobičan, s jednostavnim unutarnjim uređenjem interijera.

Zaključno o fokus-skupinama

Tijekom rasprave zamijećeno je da su mladi sudionici fokus-skupina prihvatili Dječji odjel onakav kakav im je na raspolaganju zbog navike, ali i zato što nisu bili upoznati s tim da u svijetu, pa i u Hrvatskoj, postoje odjeli, ali i knjižnice za mlade, odnosno s tim koje im sve mogućnosti mogu stajati na raspolaganju.

Međutim razvidno je da bi sudionici istraživanja voljeli imati prostor koji bi bio prilagođen njihovim potrebama, da bi interijer bilo korisno urediti prema njihovim prijedlozima jer se pokazalo da, iako imaju različite želje i vizije, njihove ideje i prijedlozi slijede navike mladih ljudi. Što se tiče samog izgleda knjižnice, sugerirano je da on bude privlačnih boja i oblika jer je to za mlade poticaj i poziv za korištenje knjižnice.

Istaknuli su također da knjižnice izvana trebaju biti dovoljno prepoznatljive i uočljive čak i iz daljine, što se može postići dobrom lokacijom ili karakterističnim arhitektonskim rješenjem zgrade.

\subsubsection{Intervjui s osobama koje rade s mladima}

Sve intervjuirane osobe rade s mladima, izravno - kao knjižničari na Dječjem odjelu, odnosno neizravno - kad im se mladi obraćaju vezano uz korištenje drugih odjela ili kad provode programe uz mlade izvan Dječjeg odjela. Prvi i drugi ispitanik (I1, I2) po zanimanju su diplomirani knjižničari i profesori hrvatskog jezika, odnosno hrvatskog i engleskog jezika, a rade na Dječjem odjelu. Ispitanik I3 profesor je hrvatskog jezika i književnosti i radi kao knjižničar na Glazbenom odjelu, odnosno na odjelu koji se odnedavno zove Mediateka. Četvrti i peti ispitanik (I4, I5) po zanimanju su diplomirani učitelj, odnosno profesor hrvatskog jezika, a voditelji su književnog kluba za mlade Dioptrija, odnosno kluba za mlade u ogranku Bili brig.

Svi su ispitanici skloni mladima i rješavanju njihovih potreba za informacijama i knjižničnom građom te osmišljavanju novih atraktivnih programa kojima bi se što veći broj mladih privukao u knjižnicu. Na tom je tragu bilo potaknuto postavljanje posebne zbirke za mlade unutar Dječjeg odjela, pa I1 zaključuje:

„A kako smo stavili jedno prije tri godine odjel za mlade, literaturu za mlade, onda recimo malo se duže zadržavaju kod nas, do 18 godina... Baš smo zato napravili taj, odvojili literaturu za mlade, pa mislim da je dosta dobro prihvaćena."

Prednost Dječjeg odjela jest mogućnost učenja naglas, odnosno dopušteno je glasno razgovarati, što na drugim odjelima nije praksa, pa I2 kaže: 
„Mogu reći da je dobro suživio taj dio različitih dobnih skupina jer je naš odjel specifičan... Osim toga dolaze dosta studenti radi zajedničkog učenja, bilo u paru ili u grupi, jer im dječji odjel pruža mogućnost pričanja naglas, ne kao tihi rad u studijskoj čitaonici, nego ovdje mogu tiho ili glasno pričati, što nama ovdje ne smeta... Isto tako srednjoškolci i osnovnoškolci dolaze zajedno učiti ili izrađivati plakate, pisati domaće zadaće, tako da je to baš lijepo, nitko nikome ne smeta.“

Ispitanici I1 i I2 slažu se da je prostor ponekad prenapučen, zbog čega se sugerira korisnicima korištenje prostorija ogranka Arbanasi koji ima velik, topao i ugodan prostor za učenje ili neke druge aktivnosti.

Za I3 važno je da se korisnici osjećaju ugodno u prostoru knjižnice, bez obzira na to o kojem se odjelu radi, jer je knjižnica uvijek bila više od same ustanove koja ima građu.

„Imate ovdje koji su po cijeli dan. Osjećaju se kao kod kuće.“

Za I4 prisutnost mladih u knjižnici posljedica je i nastojanja da im se omogući da sami traže mjesto na kojem će se najugodnije osjećati:

"Znači oni su nigdje, oni su raspršeni... Ovo su sad generacije koje samo prstom pomiču, njima baš treba multimedijalni nekakav centar."

Istaknuto je također (I5) da su današnje generacije mladih okrenute internetu, novim medijima i društvenim mrežama. Iskustvo osoba koje s njima rade potvrđuje međutim da su mladi zainteresirani i za neposredne kontakte, rasprave, raznolike teme i one programe u kojima mogu ostvariti svoje potrebe ${ }^{32}$, osobito kada se radi o komunikaciji unutar određenih programski usmjerenih skupina. Za takve programe, smatraju svi ispitanici, prostor je nužan preduvjet.

U odnosu na viđenje prostora za mlade jednoglasno je potvrđeno da mladi trebaju imati prostor za sebe jer Dječji odjel nije prilagođen mladima, iako su se korisnici naviknuli koristiti se njime u nedostatku drugih mogućnosti. Pritom ispitanici I4 i I5 posebno izdvajaju problem intimnosti:

„Nama ovdje fali malo intimnosti gdje možemo na miru, je li, pričati, komentirati, jer se ovdje često zna dogoditi gužva... Mislim da njima dolje fali intimnost, ali i nama ovdje.“(I5)

32 Osobito je takav pristup razvidan iz zanimanja za teme unutar „Svaštarnice“ koje se učestalo mijenjaju. Prema iskustvu I2, prva generacija bila je zainteresirana za estradu, javnost i medije, druga je bila zatvorenija, treću su zanimale razne teme, a četvrta je usmjerena prema čitanju i knjizi te ima široko polje zanimanja. 
Vezano uz mogućnost proširenja postojeće knjižnične zgrade i oblikovanja posebnog prostora za mlade, ispitanici su iznijeli svoja viđenja temeljnih obilježja prostora za mlade i toga kako bi trebale izgledati njegove pojedine cjeline. Ispitanik I1 smatra da se unutarnjim rasporedom i uređenjem može sugerirati kako će se mladi ponašati u prostoru koji im je namijenjen. Prostor za knjige zamišlja kao topao i ugodan, s velikim razmakom između polica kako bi se moglo lakše prolaziti, šetati i komunicirati u skupinama, a

„...prostor za učenje isto tako ugodan, stolove bi ovako okrugle stavili jer prostor za učenje je najčešće upravo takav gdje oni uče u grupama..., šašave, lude stolice, vesele, vedre, nikad to ne bih stavila za mlade u jednu boju.“

Ispitanik I2 prostor za mlade zamišlja kao mjesto za druženje, opuštanje, poput dnevnog boravka.

„Nekako dnevni boravak gdje oni mogu opušteno sjediti, ali i stolove i stolice za nekakvo koncentriranije radnje, učenje, čitanje, listanje i ovih novih medija, pomagala. Ali isto tako da mogu sa slušalicama lijepo slušati neke sadržaje, da im nitko ne smeta, da mogu igrati neke društvene igre.“

Prostor za mlade ispitanik I3 zamišlja tako da bude podijeljen u tri dijela. Prvi dio bio bi namijenjen kreativnim radionicama, drugi - filmoteka - namijenjen gledanju i komentiranju filmova, a treći bi trebala biti slušaonica.

„Prostor za mlade vidim kao prostor podijeljen u tri kategorije jer smatram kako bi jedan veliki bio džumbus.“

Što se tiče priprema za nove prostore za mlade, ispitanik I4 polazi od toga da bi prostor za mlade trebao biti neobičan, više od same zgrade, te predlaže da bi svakako trebalo mlade uključiti u samo uređenje knjižnice kako bi im prostor bio privlačniji i bliži njihovim ukusima:

„A sad, neka moja osobna preferencija je radikalnija, tipa Harry Potter dnevni boravak njihov, jedan dio nekakvo onako drvo, ali tople, tamne boje, tako nešto zamišljam, iako znam da ima ekipe koja bi samo aluminij i sve bijelo.“

S tim se stajalištem slaže i ispitanik I5 koji kaže:

„Super mi je dnevni boravak, koliko djece ima slobodan sat i gdje će nego u kafić, a ovako bi mogli u knjižnicu. To bi ih privuklo knjižnici.“

Polazeći od toga da je jako važan sam izgled knjižnice ili prostora namijenjena mladima, jer mladi veliku pažnju pridaju vizualnom izgledu, ispitanik I5 kaže: 
„Morao bi nekako izgledom biti zanimljiv jer je njima bitno i kako knjiga izgleda, korice, a kamoli ne kako izgleda ambijent u kojem se nalaze.“

Naposljetku, zanimalo nas je mišljenje ispitanika o tome tko je ključan čimbenik realizacije ideje o prostoru za mlade unutar Gradske knjižnice u Zadru. Kad se poveo razgovor o tome zašto Gradska knjižnica još uvijek nije pokrenula projekt obnove napuštene zgrade uz postojeću, ispitanik I1 uvjeren je da realizacija knjižnice za mlade najviše ovisi o ravnateljici i upravljačkoj strukturi grada, a I4 smatra da je grad veliki „zid“ kad su u pitanju projekti koji se tiču kulture i mladih te da bi se trebalo više okrenuti nekim udrugama:

„Grad je tu jedan veliki zid. Možeš bacati lopte koliko god hoćeš, ali to se tako odbija."

\subsubsection{Zaključno o provedenim intervjuima}

Ispitanici su pokazali veliko zanimanje za mogućnost izgradnje nove knjižnice/odjela za mlade i pritom ukazali, na temelju vlastitih iskustava, na najvažnije elemente o kojima bi trebalo voditi računa, a koji su gotovo identični elementima predloženim u fokus-skupinama. Prema njihovu nepodijeljenom mišljenju, mladi grada Zadra trebaju prostor koji će ih privlačiti u knjižnicu, podržavati njihove ideje, omogućiti da se razvijaju i postanu korisni članovi zajednice.

\section{Polazišta za novu knjižnicu za mlade u Zadru}

$\mathrm{Na}$ osnovi provedenog istraživanja te proučene stručne literature i vlastitih zamisli, autorice su naznačile osnovne ideje vezane uz buduću Knjižnicu za mlade Zadar, zamišljenu u neposrednoj blizini Gradske knjižnice Zadar, u objektu s njezine zapadne strane. Valja napomenuti da namjera nije bila izraditi programsku osnovu, već ukazati na izazove pred kojima će se naći knjižničari i arhitekti ako/ kad dođe do realizacije širenja postojeće knjižnice na obližnju zgradu. Polazeći od toga da su fiksni elementi objekta (stupovi, fasadne stijene i instalacijski kanali) zadani, valja ustrajati u tome da se ostvare zamisli o fleksibilnosti, kompaktnosti, pristupačnosti i modularnosti te da se promisli o idejama koje su iznijeli ispitanici tijekom ovog istraživanja.

Prednosti ponuđenog rješenja:

- lokacija zgrade je na atraktivnom položaju u gradu

- na prihvatljivoj je udaljenosti od srednjih škola

- u blizini je frekventna autobusna stanica

- nalazi se uz sadašnju zgradu Gradske knjižnice Zadar. 
Nedostaci ponuđenog rješenja:

- nije uočljiva s glavnih ulica

- malen broj parkirnih mjesta

- zadani unutarnji gabariti otežavaju povezanost među odjelima.

Smatrajući da bi poslanje knjižnice za mlade Zadar bilo educirati, poticati i povezati, podržavati kulturni i društveni razvoj mladih u zajednici, zamišljamo prostor koji će omogućiti proširenje postojećih usluga i niz novih. Na tom tragu, vizija budućeg prostora za mlade u Zadru temelji se na saznanjima o zanimanjima mladih i njihovim preferencijama, a poglavito na prijedlozima iznesenim u provedenome istraživanju, kako mladih ispitanika tako i intervjuiranih knjižničara. Novi bi prostori trebali osigurati da Knjižnica bude prepoznatljivo središte za mlade, privlačno mjesto za učenje, zabavu i druženje mladih u zajednici te mjesto nadahnuća za kreativne sadržaje koje osmišljavaju, u kojima sudjeluju i kojima se obraćaju zajednici.

Koncept knjižnice za mlade zasniva se na ključnim riječima: zanimljiva, ugodna, korisna, fleksibilna, uzbudljiva, inspirativna i inovativna te slobodna, otvorena i dostupna. ${ }^{33}$

U takvu konceptu, koji slijedi i nadopunjuje osnovne ideje Knjižnice za mlade u Karlovcu, postavljeno je da knjižnica bude mjesto susreta, komunikacije i zabave te izvor kvalitetnih informacija te mjesto u kojemu svoje informacijske, komunikacijske, društvene i kulturne potrebe mogu zadovoljiti mladi pojedinci i skupine. Važnim nam se čini istaknuti da novi prostor treba nadahnuti i omogućiti poticanje prijenosa znanja te upoznavanje mladih s novim spoznajama u društvu. U novom prostoru uporaba novih tehnologija trebala bi biti conditio sine qua non, a uporaba tih tehnologija jednakomjerno zastupljena i u odnosu na promišljeno provođenje slobodnog vremena i u odnosu na osiguravanje uvjeta za učenje i poticanje kreativnosti mladih. ${ }^{34}$

\section{Zaključno}

Vjerujući da je važno prihvatiti da mladi najbolje znaju što im je privlačno i korisno, provedenim se istraživanjem nastojalo doći do stavova mladih vezanih uz oblikovanje prostora u kojemu bi se nudili programi koji ih najviše privlače i u kojima bi se rado vidjeli kao aktivni sudionici, uključujući programe kojima bi se mladi predstavljali drugim članovima zajednice. Stajališta i prijedlozi mladih ispi-

33 Vlastite ideje o tome kako bi se mogao organizirati novi odjel za mlade u Gradskoj knjižnici Zadar detaljno je razradila studentica M. Kasap u svom diplomskom radu koristeći se alatom za vizualizaciju ArchiCAD.

34 Usp. Gradska knjižnica „Ivan Goran Kovačić“. [citirano: 2015-09-09]. Dostupno na http:// www.gkka.hr/?page_id=10. 
tanika potvrdili su polaznu pretpostavku da mladi žele svoj prostor i da imaju ideje o tome kako taj prostor urediti te da su knjižničari i stručnjaci koji rade s mladima uvjereni bi se u knjižnicu mogao privući veći broj mladih ako bi njima namijenjen prostor bio privlačan, funkcionalan i ugodan.

Korištenjem kvalitativnih metoda postignuto je to da su se svi ispitanici (u fokus-skupinama i prilikom intervjua) osjećali ugodno te da su otvoreno izražavali svoja stajališta i ponudili vlastita viđenja budućeg prostora namijenjena mladima $\mathrm{u}$ gradu Zadru.

Slijedom istraživačkih pitanja utvrđeno je da su se mladi prilagodili prostorima koji su im na raspolaganju, iako prema njihovu mišljenju nema dovoljno prostora za učenje i druženje. Nadalje, utvrđeno je da mladi nisu upoznati s konceptom, odnosno postojanjem odjela, odnosno knjižnica za mlade, ali su ih slikovni prilozi potaknuli na raspravu i komentare te isticanje potrebe za odvojenim prostorom za njihove aktivnosti. Ponuđeni slikovni prilozi pobudili su zanimanje mladih ispitanika i potaknuli ih na promišljanje budućeg prostora u koji bi rado dolazili i u kojem bi se osjećali ugodno. Posebno su se zainteresirali za dizajn, odnosno interno oblikovanje prostora te, polazeći od vlastitih iskustava i potreba, istaknuli one elemente koji bi trebali voditi knjižničare i arhitekte prilikom osmišljavanja prostora i programa buduće knjižnice/odjela za mlade. Pritom je bilo razvidno da su privrženiji građevinama i namještaju koji ima netipičan izgled. Iako se pokazalo da imaju različite želje i vizije različitih prostora, nameće se zaključak da bi interijer bilo korisno urediti prema njihovim prijedlozima, poglavito kad se radi o korištenju namještaja, privlačnih boja i oblika, jer su vedri tonovi za mlade poticaj i poziv za korištenje knjižnice. Utvrđeno je također da postojeći prostori unutar odjela namijenjenih djeci mogu tek djelomično odgovoriti na potrebe mladih koji su se naviknuli dolaziti na te odjele, ali da oni ne mogu privući nove korisnike ni odgovoriti na rastuće potrebe mladih u digitalnom okruženju. Toga su napose svjesni oni stručnjaci koji s mladima nastoje ostvariti bar dio programa. Njihovo je mišljenje da se jedino uz nove, osmišljene i suvremeno oblikovane prostore te veći broj stručnjaka mogu ponuditi programi za sve skupine mladih stanovnika grada.

Nesumnjivo je da je problem slobodnog vremena mladih jedan od ključnih problema društva i da valja sustavno „osluškivati“ što mladi žele, planirati kako ih uključiti kao nositelje različitih aktivnosti te da donositelje odluka valja odgovarajućim podacima i prijedlozima uvjeriti da je narodna knjižnica svojim poslanjem $i$ iskustvom idealno uporište za hrabre, dugo iščekivane iskorake.

Ovo istraživanje inicirano je i provedeno za potrebe diplomskog rada, pa je stoga bilo ograničeno vremenom i prostorom. Drugi dio istraživanja, proveden nakon obrane diplomskog rada, bio je potaknut upravo sviješću o potrebi uključivanja stručnjaka koji rade s mladima, jer njihovo iskustvo i poznavanje rada s mladima otvara i druga motrišta. Buduća istraživanja svakako bi trebala uključiti veći broj mladih ispitanika te roditelje, pedagoge, donositelje odluka i druge dionike koji 
mogu imati važnu ulogu pri zagovaranju ideje o proširenju Gradske knjižnice Zadar, poglavito u odnosu na potrebe mladih. Također, bilo bi zanimljivo usporediti iskustva drugih hrvatskih knjižnica koje su izgradile/oblikovale prostore za mlade ili to planiraju učiniti,.

\section{LITERATURA}

Architectural Record. [citirano: 2015-04-21] Dostupno na http://www.architecturalrecord.com/

Architecture media. [citirano: 2015-04-21]. Dostupno na https://architecturemedia. com/magazines/architecture-australia/

Canadian Architecture. [citirano: 2015-04-21]. Dostupno na https://www.canadianarchitect.com/

E-architect. [citirano: 2015-04-21]. Dostupno na https://www.e-architect.co.uk/

Edwards, Brian. Libraries and learning resource centres. 2nd ed. Amsterdam ; London : Architectural Press, 2009.

Faulkner-Brown, Henry. Some thoughts on the design of major library buildings. // Intelligent library buildings: Proceedings of the 10th Seminar of IFLA's Library Buildings and Equipment Section / edited by Marie-Françoise Bisbrouck and Marc Chauveinc. The Hague, Netherlands, 1997 1997. Str. 14-26.

Gradska knjižnica „Ivan Goran Kovačić“. [citirano: 2015-09-09]. Dostupno na http:// www.gkka.hr/?page_id=10

Gradska knjižnica Zadar. [citirano: 2015-10-15] Dostupno na http://www.gkzd.hr/?q=hr/ djecji

Harding, Laura. Narellan Library. // American Architecture (May-June 2006), 80-86.

IFLA-in i UNESCO-ov manifest za narodne knjižnice. // IFLA-ine smjernice za narodne knjižnice. / uredile Christie Koontz i Barbara Gubbin. Zagreb : Hrvatsko knjižničarsko društvo, 2011.

IFLA-ine smjernice za narodne knjižnice. // uredile Christie Koontz i Barbara Gubbin . Zagreb : Hrvatsko knjižničarsko društvo, 2011.

IFLA library building guidelines: developments \& reflections / edited on behalf of IFLA by Karen Latimer and Hellen Niegaard. München: K.G. Saur, 2007.

Ikin, Su. Our library their space: The Dunedin City Library teen space. // Aplis 23, 2(June 2010). [citirano: 2015-10-20]. Dostupno na https://www.questia.com/library/journal/1G1-231313206/our-library-their-space-the-dunedin-city-library 
Lammiman, Jean; Michel Syrett. Cool generacija: nova poslovna filozofija. Zagreb : Naklada Ljevak, 2005.

Lidwell, William; Kristina Holden; Jill Butler. Univerzalna načela dizajna. Zagreb : Mate, 2013.

Lozanovska, Mirjana ; Leilei Xu. Children and university architecture students working together: A pedagogical model of children's participation in architectural design. // CoDesign, 9, 4(2013). [citirano: 2015-10-20]. Dostupno na http://dx.doi.org/10.10 80/15710882.2012.693187

Schmitt, Rita. Novi koncepti za knjižnice za mladež. Zagreb : Goethe Institut, 2001. [citirano: 2015-07-31]. Dostupno na http://www.goethe.de/mmo/priv/568480-STANDARD.pdf

Smjernice za knjižnične usluge za mladež: prerađeno izdanje Smjernica koje je 1996. objavio Stalni odbor Selekcije knjižnica za djecu i mladež. / priređivači Pat Muller i Ivan Chew. Zagreb : Hrvatsko knjižnično društvo, 2009.

Standardi za narodne knjižnice u Republici Hrvatskoj. // Narodne novine 58, 1071(1999). [citirano: 2017-08-09] Dostupno na http://narodne-novine.nn.hr/clanci/sluzbeni/270810.html

Stričević, Ivanka; Srećko Jelušić. Knjižnične usluge za mlade: modeli i koncepti. // Vjesnik bibliotekara Hrvatske 53, 1(2010), 1-34.

Stropnik, Alka. Knjižnica za nove generacije : virtualni sadržaji i usluge za mlade. Zagreb : Hrvatsko knjižničarsko društvo, 2013.

Thompson, Geodfrey. Planning and design of library buildings. London: Butterworth Architecture, 1989.Tibljaš, Verena. Kako izgleda dobra narodna knjižnica za mlade. // Slobodan pristup informacijama : 7. i 8. okrugli stol : zbornik radova / urednice Aleksandra Horvat i Loris Bučević Sanvincenti. Zagreb: Hrvatsko knjižnično društvo, 2009. Str. 146-151.

Whitehead, Terri. Community action. // Canadian Architecture 1(2005), 20-24.

Zrile, Marina; Dina Vozab; Mladen Blagojević. Pribor za prvu pomoć za visoko obrazovanje. [citirano: 2015-07-21]. Dostupno na

http://www.ffzg.unizg.hr/kssd/files/Pribor\%20za\%20prvu\%20pomo\%C4\%87\%20 za\%20visoko\%20obrazovanje.pdf 